\title{
Methionyl human growth hormone in Turner's syndrome
}

\author{
C RONGEN-WESTERLAKEN, ${ }^{*} \mathrm{~J}$ M WIT, ${ }^{*} \mathrm{~S}$ L S DROP, $\dagger$ B J OTTEN, $\ddagger$ W OOSTDIJK, \\ H A DELEMARRE-V D WAAL, $\S \mathrm{M}$ H GONS, ${ }^{* *}$ A BOT, $\ddagger$ AND J L VAN DEN BRANDE* \\ Departments of Paediatrics, *University Hospital for Children and Youth "Het Wilhelmina Kinder- \\ ziekenhuis", State University, Utrecht, †Sophia Children's Hospital, Erasmus University, Rotterdam, \\ $\ddagger$ Radboud Hospital, University of Nijmegen, \State University, Leiden, §Free University, Amsterdam, and \\ **Academic Medical Centre, University of Amsterdam, and $\ddagger \neq$ Department of Endocrinology, Growth, and \\ Reproduction, Erasmus University, Rotterdam, The Netherlands
}

SUMMARY Sixteen girls with Turner's syndrome aged $7 \cdot 9-15 \cdot 2$ years (bone ages $7 \cdot 0-11 \cdot 8$ years) were given methionyl growth hormone (somatrem) $4 \mathrm{IU} / \mathrm{m}^{2}$ body surface daily, corresponding to $0.9 \mathrm{IU} / \mathrm{kg} /$ week. During one year of treatment their mean (SD) height velocity increased from 3.4 $(0.9)$ to $7.2(1.7) \mathrm{cm} /$ year and height prediction from $148 \cdot 2(4.4)$ to $150 \cdot 0(4.4) \mathrm{cm}$. All the girls except one had a height velocity increment of more than $2 \mathrm{~cm} /$ year and these velocities are above the age references for girls with Turner's syndrome. The girl with a low growth response had antibodies against growth hormone with high binding capacity $(3.7 \mathrm{U} / 1)$. The height velocity increment was inversely correlated with age and bone age, but this might be partly due to the somewhat higher dosage $/ \mathrm{m}^{2}$ body surface and $\mathrm{kg}$ body weight that the younger patients were given because of the rounding off of the dose. The better results of our study compared with those of other workers who used similar dosages but did not give the drug as often suggest that giving it daily might have increased the growth response as it does in children deficient in growth hormone.

Turner's syndrome comprises a number of physical abnormalities including sexual infantilism, webbed neck, cubitus valgus, and poor growth velocity that results in short stature. The growth pattern has been well documented, and the reported mean adult height varies between 141.0 and $147.8 \mathrm{~cm}^{1-3}$

The mechanism underlying this failure to grow is not known, but it is generally believed that the defect is primarily cellular. ${ }^{4}$ Peak plasma concentrations of growth hormone have been reported as normal by some authors but as low by others after various pharmacological provocation tests. ${ }^{56}$ Ross et $\mathrm{l}^{7}$ studied the 24 hour growth hormone profiles in 30 patients with Turner's syndrome, and observed that between 9 and 20 years of age these girls had 24 hour growth hormone profiles with low integrated growth hormone concentrations, peak amplitudes, and peak frequencies compared with those of age matched controls. In contrast, these values were not significantly different between 2 and 8 years of age.

In a number of short term studies, treatment of patients with Turner's syndrome by human pituitary growth hormone (sometimes given simultaneously with anabolic steroids) gave divergent results concerning growth velocity. ${ }^{8-14}$ Until recently wider use was impossible because the supply was limited, but since 1985 biosynthetic growth hormone produced by recombinant deoxyribonucleic acid (DNA) technology has been widely available. Biosynthetic methionyl human growth hormone (somatrem) in a supraphysiological dose given three times a week has been used for patients with Turner's syndrome with favourable results. ${ }^{15} 16$ Similar results have been obtained with pituitary derived growth hormone.${ }^{17}$ So far there are no data on the effect of giving growth hormone daily, though in children with growth hormone deficiency this has been shown to improve the growth response. ${ }^{18-20}$

In this report we describe the response to somatrem $4 \mathrm{IU} / \mathrm{m}^{2}$ body surface given subcutaneously once a day for 12 months.

\section{Patients and methods}

Sixteen girls with Turner's syndrome were entered into the study. For inclusion the children had to 
meet the following criteria: age over 6 years, height more than 2.5 standard deviations below the mean for age, ${ }^{21}$ a growth velocity below the 25 th percentile for bone age, ${ }^{22}$ and bone age less than 12 years assessed by the method of Tanner and Whitehouse (TW 2, 20-bones). ${ }^{23}$ Patients were excluded if they had any endocrine or metabolic disorder, if they were taking other drugs, or if there was a suspicion of psychosocial dwarfism. The diagnosis of Turner's syndrome was confirmed by lymphocyte chromosomal analysis. Children with monosomy $\mathrm{XO}$ as well as with mosaicisms were included, unless the mosaicisms contained a Y chromosome. Ages ranged from 7.9 to 15.2 years (mean 11.7 ) and bone ages from $7 \cdot 0$ to $11 \cdot 8$ (mean $10 \cdot 2)$. (table 1$)$.

Two standard growth hormone provocation tests (the arginine infusion test and the exercise test), and a growth hormone releasing factor test were performed. Arginine hydrochloride $(0.5 \mathrm{~g} / \mathrm{kg}$ body weight to a maximum of $30 \mathrm{~g}$ ) was given intravenously over 30 minutes. Blood was taken 30 minutes before the infusion, at the time it started, and then $15,30,45,60,90,120$, and 150 minutes later for determination of growth hormone concentrations. The exercise test comprised 30 minutes of strenuous physical exercise on a bicycle ergometer, and blood samples were taken from an indwelling venous catheter at the time the test started, and 10, 20, and $\mathbf{3 0}$ minutes later. For the growth hormone releasing factor test synthetic growth hormone releasing factor $1 \mu \mathrm{g} / \mathrm{kg}$ body weight was used (KabiVitrum, Stockholm, Sweden). Blood samples were taken 30 minutes before it was given, at the time it was given, and at $15,30,45,60$, and 120 minutes later. Determinations of growth hormone concentrations were performed in the laboratories of the participating centres. The various assays were compared through a series of test samples, and the growth hormone concentrations obtained from patients' serum samples were corrected for systematic assay differences.

The children received somatrem $4 \mathrm{IU} / \mathrm{m}^{2}$ body surface daily; if the measurement was between 0.60 and $0.86 \mathrm{~m}^{2}, 3 \mathrm{IU}$ were given, and if it was between 0.87 and $1.20 \mathrm{~m}^{2}, 4 \mathrm{IU}$ were given. The mean (SD) growth hormone dose $/ \mathrm{m}^{2} /$ week was $26 \cdot 2(2 \cdot 4)$. Expressed as IU/ $\mathrm{kg} /$ week this is equivalent to 0.92 $(0 \cdot 26)$. Somatrem was prepared by KabiVitrum AB (Stockholm, Sweden) in rubber sealed phials containing 4 IU (about $1.7 \mathrm{mg}$ ) as a sterile lyophilised powder containing $37 \mathrm{mg}$ glycine and $0.7 \mathrm{mg}$ sodium phosphate. The parents were carefully instructed about how to reconstitute the drug solution. Somatrem was injected subcutaneously by the children or the parents according to a standardised procedure, and the site of injection was changed daily. The children received no additional drugs except children aged over 13 who received low dose ethinyloestradiol $(0 \cdot 1 \mu \mathrm{g} / \mathrm{kg}$ body weight/day (cases $1,8,10$, and 11).

Table 1 Selected clinical data

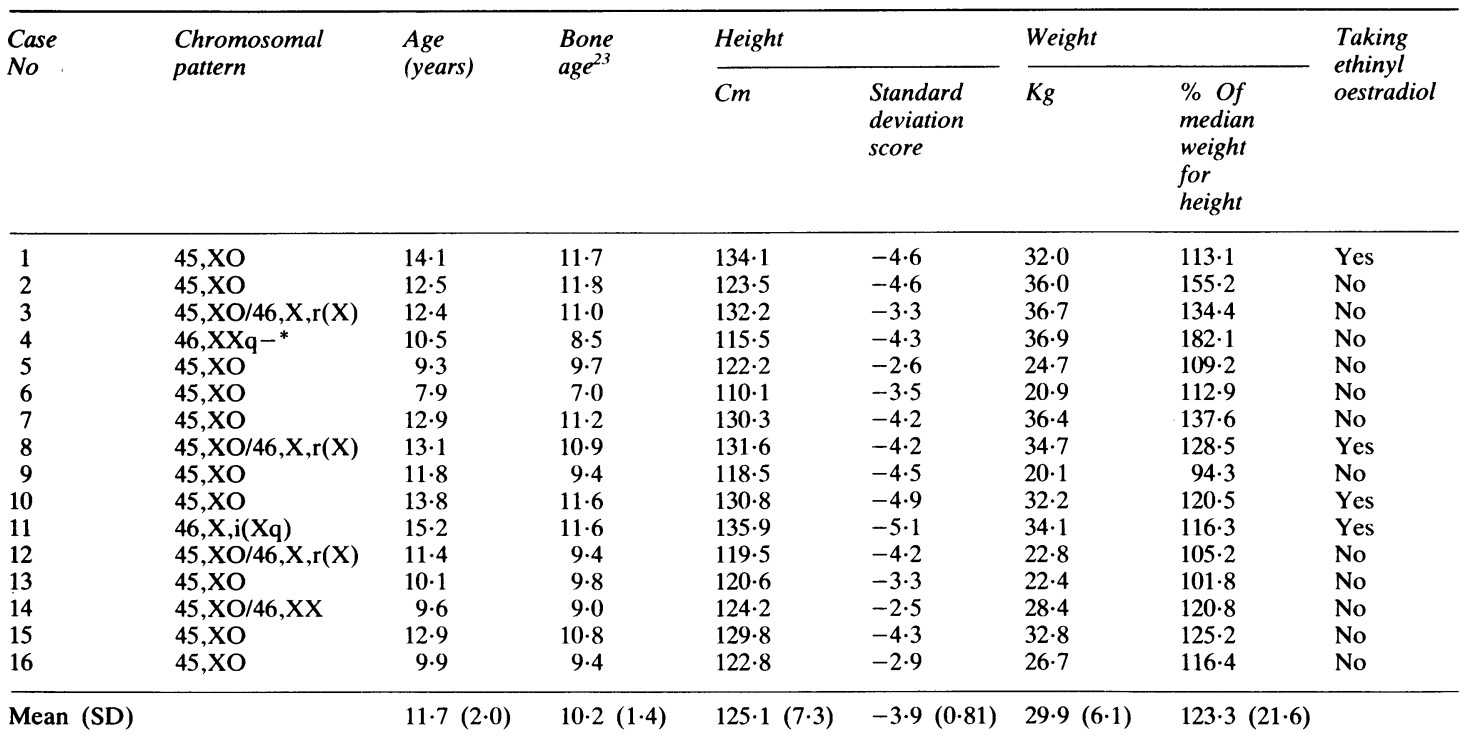

*46,XXq- =46,XX,-X,+der(X), del(Q21 - - $\mathrm{Q}$ ter $)$. 
The response of height to somatrem was analysed by measuring height when standing with a Harpenden stadiometer after $4,8,12,26,39$, and 52 weeks of treatment. The short term effect on growth velocity was investigated by measuring height after 4,8 and 12 weeks of treatment. Heights were always measured at the same hour of the day, and the measurements were performed four times by each of two investigators. The average of the means of both investigators was used for further calculations. From six months onwards measurements were made by one investigator, and the mean of four measurements was used for further analysis.

Heights were expressed as standard deviation scores using the recent Dutch cross sectional references. ${ }^{2 P}$ The growth velocity was expressed as $\mathrm{cm} /$ year and for comparison the velocity curves for girls with Turner's syndrome prepared by Ranke $e t$ $a l^{24}$ were used. Sitting height was measured by standard techniques. The ratio sitting height:subischial leg length was transformed to a standard deviation score using the reference values from the Zurich longitudinal growth study (RH Largo and $\mathrm{M}$ Zachmann, personal communication). Weight was measured on an accurate scale and expressed as a percentage of the median for height. ${ }^{21}$

Skinfold thickness was measured at the left biceps, triceps, and subscapular site, according to standard procedures. ${ }^{25}$ The left arm circumference was measured halfway between the acromion and olecranon. The muscle/bone area $\left(\mathrm{mm}^{2}\right)$ in the left upper arm was estimated using the equation $\pi$ .$(C / 2 \pi(b+t) / 40)^{2}$, where $C$ is the arm circumference $(\mathrm{mm}), \mathrm{b}$ the biceps skinfold thickness $(0 \cdot 1 \mathrm{~mm})$ and $\mathrm{t}$ the triceps skinfold thickness $(0 \cdot 1 \mathrm{~mm})$. These values were compared with Dutch age references. ${ }^{26}$ Radiographs of the hands were taken at 0,6 , and 12 months and assessed by one of the authors (AB) using the atlas of Greulich and $\mathrm{Pyle}^{27}$ and the method of Tanner and Whitehouse. ${ }^{23}$ Values for height were calculated using the tables of Bailey and Pinneau. ${ }^{27}$

Before the start of treatment, and at three monthly intervals during treatment, blood samples were taken for estimation of concentrations of haemoglobin, erythrocytes, leucocytes, platelets, and total eosinophils, leucocyte differentiation, and haematocrit. Biochemical assessment of serum samples included blood urea nitrogen and creatinine concentrations, alkaline phosphatase and transaminase activities, electrolytes, albumin, and thyroxine concentrations. Urine samples were analysed by routine methods for the presence of glucose, protein, blood, and sediment. Urinary concentrations of retinol binding protein were measured with the Hyland Disc nephelometer (Hyland, Nivelle, Belgium) by the technique of Renckens et al. ${ }^{28}$ The antiserum used was rabbit antiretinol binding protein (Dako, Glostrup, Denmark) and the detection limit was $0 \cdot 12 \mathrm{mg} / 1$.

The immunological screening consisted of determinations of circulating immune complexes (CIq method $^{29}$ ), antibodies against growth hormone and antibodies against Escherichia coli proteins. Most determinations of circulating immune complexes were done in the central laboratory of the blood

Table 2 Growth velocity (cm/year)

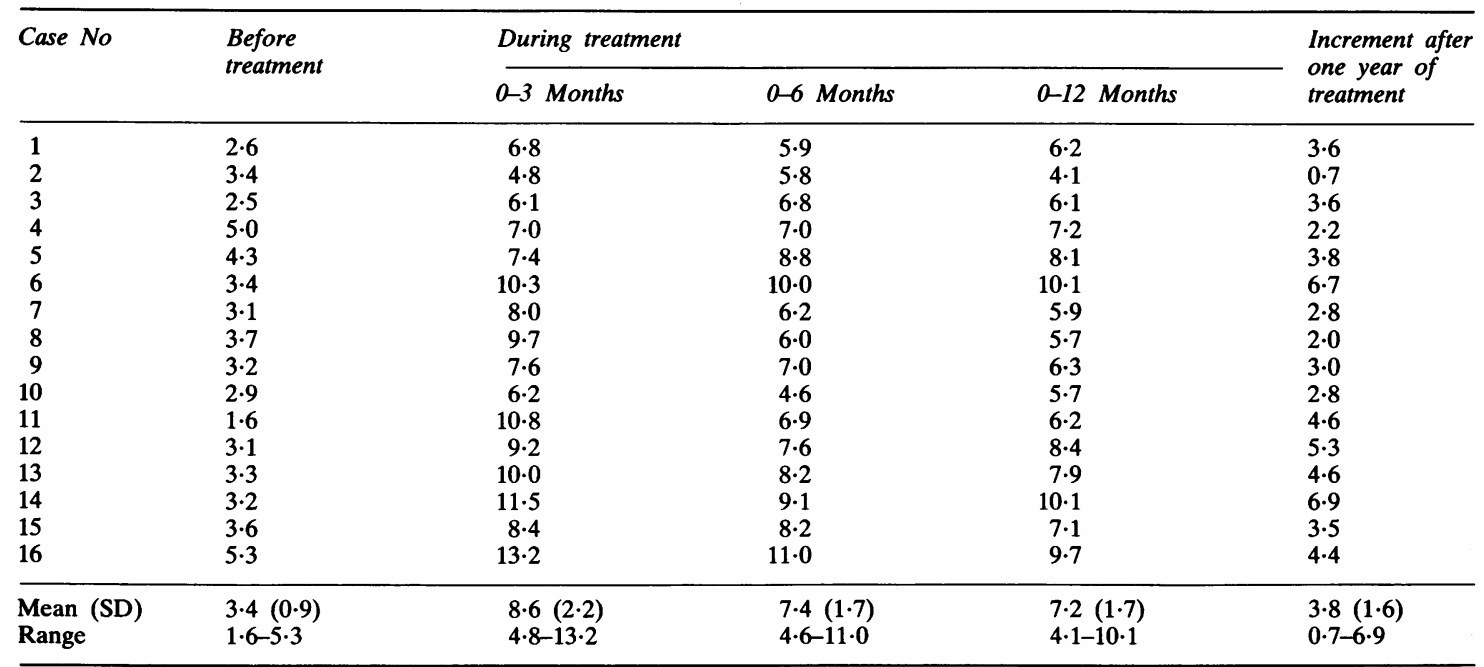




\section{Rongen-Westerlaken, Wit, Drop, et al.}

transfusion service in Amsterdam (normal range $<7 \%$ ) and some in the laboratories of the Free University in Amsterdam, and of the Erasmus University, Rotterdam (normal range $<15 \%$ ). Antibodies against growth hormone were measured at the endocrine laboratory of the Bergweg Hospital in Rotterdam by determining the percentage binding of ${ }^{125} \mathrm{I}$ labelled human growth hormone before and after the addition of $25 \mu \mathrm{U}$ somatrem. In 75 controls the percentage binding ranged between 2 and $16.7 \%$, and 0.5 and $11.5 \%$, respectively. If the binding percentage was greater than $16.7 \%$ it was an indication that antibodies against growth hormone were present. If the binding was greater than $15 \%$ a Scatchard plot was made to determine the binding capacity and $K$ value of the strongly binding and weakly binding antibodies. Antibodies against $E$ coli proteins were measured by an enzyme linked immunosorbent assay (ELISA) by KabiVitrum (Stockholm, Sweden).

Results are expressed as mean (SD), except where indicated otherwise. The paired Student's $t$ test and the Wilcoxon matched pairs signed rank test were used for the analysis of changes within the groups. The correlations between various measurements were made by Spearman's correlation test.

\section{Results}

Table 2 shows the individual growth velocities before and during treatment with somatrem, and the increments while receiving treatment. There was a significant increase in the mean growth velocity from 3.4 to $7.2 \mathrm{~cm} /$ year in the first 12 months $(p<0 \cdot 001)$. When compared with the Turner growth velocity reference curves ${ }^{24}$ all growth velocities before treatment were within the reference range, whereas all growth velocities after the start of treatment except one were well above this range (fig 1). The mean cumulative growth velocities are shown in fig 2.

During the first year of treatment the mean (SD) increase in bone age was $1.0(0.4)$ years when assessed by the method of Tanner and Whitehouse ${ }^{23}$ and $1.1(0 \cdot 8)$ when assessed by that of Greulich and Pyle. ${ }^{27}$ The increase in bone age assessed by the method of Tanner and Whitehouse was $0.4(0 \cdot 3)$ in the first semester, not statistically different from that in the second semester $(0 \cdot 6(0 \cdot 3))$. According to the method of Greulich and Pyle the increase in bone age during the first semester was $0.2(0.4)$, significantly less than that in the second semester $(0.9(0.6), \mathrm{p}<0 \cdot 001)$. The mean (SD) height prediction (based on the bone age readings with the Greulich and Pyle atlas and the Bailey Pinneau

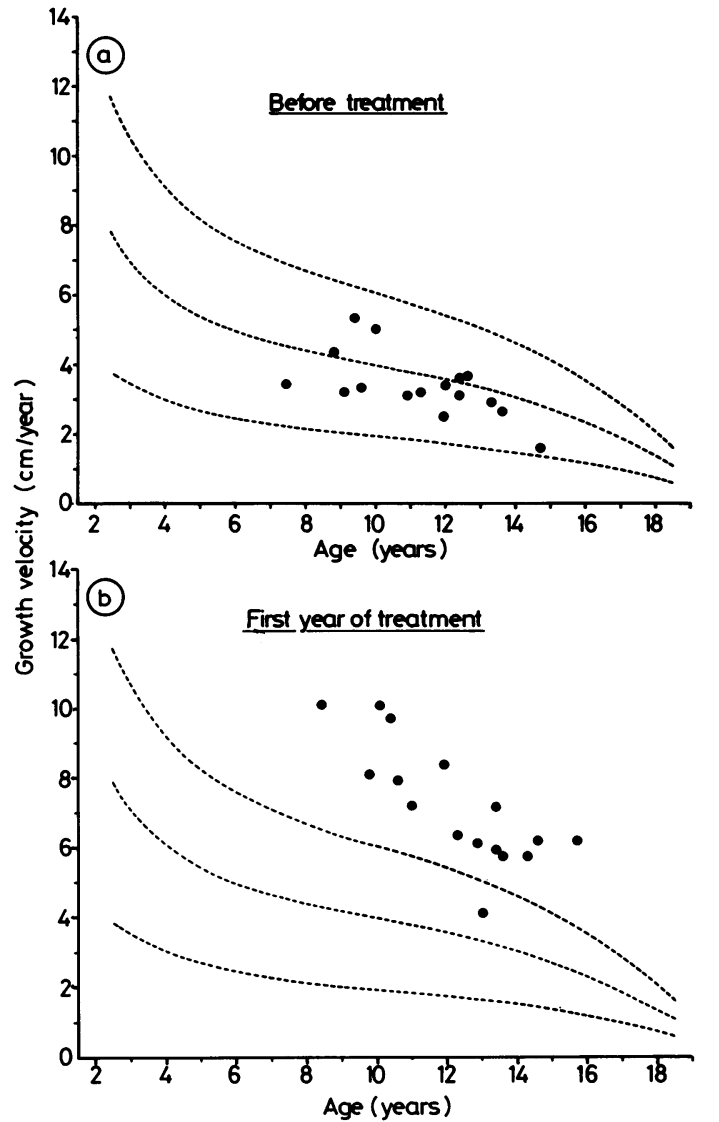

Fig 1 Growth velocities before and during treatment compared with the growth velocity reference curves for Turner's syndrome. $^{24}$

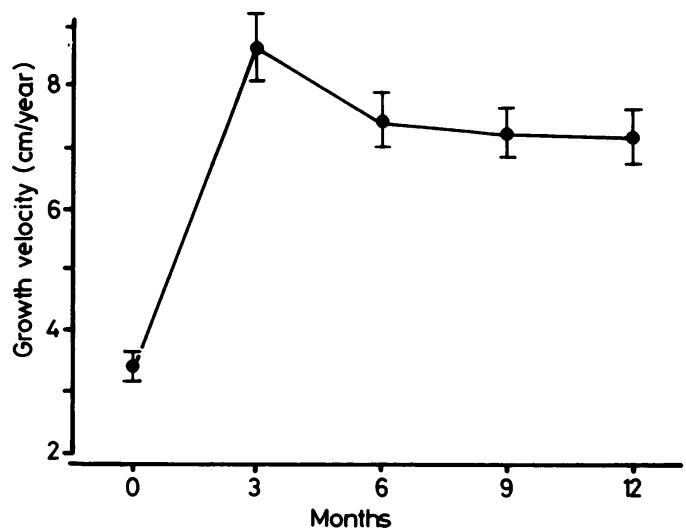

Fig 2 Mean (SEM) cumulative growth velocities. 
tables) increased from $148 \cdot 2(4 \cdot 4)$ to $150 \cdot 0(4 \cdot 4) \mathrm{cm}$ $(p=0 \cdot 06)$.

There were no significant changes of the triceps, biceps, and subscapular skinfold thicknesses, weight for height, muscle/bone area, or the ratio of the sitting height:subischial leg length expressed as standard deviation score for bone age.

There was a weak but significant negative correlation between the growth velocity increment after 12 months of treatment and chronological age $(\mathrm{r}=-0.51, \mathrm{p}<0.05)$, and bone age $(\mathrm{r}=-0.55$, $p<0.05)$. The rounding off of the growth hormone dose meant that the average older girls received less growth hormone per $\mathrm{m}^{2}$ body surface or kilogram body weight than the younger girls. This is illustrated by the negative correlation between age and growth hormone dose in IU/ $\mathrm{kg} /$ week $(\mathrm{r}=-0.67$, $\mathrm{p}<0.01)$. As the height velocity increment is also correlated with the growth hormone dose in IU/kg/ week $(r=0.54)$, it is possible that the inverse correlation between height velocity increment and age is at least partly a dosage effect. Neither the growth velocity before treatment nor the delay in bone maturation correlated with the growth velocity increment after 12 months of treatment. The growth velocity increment after four weeks did not correlate significantly with the increment after 12 months $(r=0.43)$, but did after 8 and 12 weeks $(r=0.57$, $\mathrm{p}<0.05$, and $\mathrm{r}=0.73, \mathrm{p}<0.01$, respectively).

The maximum growth hormone concentrations after arginine infusion were between 2 and $68 \mathrm{mU} / \mathrm{l}$ (mean 24), after exercise between 1 and $50 \mathrm{mU} / \mathrm{l}$ (mean 22), and after growth hormone releasing factor between 7 and $137 \mathrm{mU} / \mathrm{l}$ (mean 40). In six girls (aged 9.3 to 13.8 years, mean 11.9) the peak growth hormone concentrations during the two provocation tests were below $20 \mathrm{mU} / \mathrm{l}$. When the patient with the high concentration of antibodies against growth hormone was excluded, the mean (SD) increment was $3.0(0.7) \mathrm{cm}$-year compared with $4.5(1.5) \mathrm{cm} /$ year in the remaining children.

To see if there were any predictors of the effect of treatment with growth hormone in patients with Turner's syndrome we calculated the correlation coefficients of the peaks of the different growth hormone provocation test against the increment of height velocity as well as the height velocity itself. None of these correlated significantly with the growth response.

The haematological and biochemical measurements in blood and urine did not show any significant changes. The urinary excretion of retinol binding protein remained below the detection limit in all children. In seven of 15 patients antibodies against growth hormone were found during treatment. Binding capacity was low $(<1.3 \mathrm{U} / \mathrm{l})$ in six children. One child (case 2) showed antibodies against growth hormone with a high binding capacity of $3.7 \mathrm{U} / \mathrm{l}$. She had a growth velocity increment of $0.7 \mathrm{~cm} /$ year, which is much lower than the mean growth velocity increment. In addition, her absolute growth velocity while receiving treatment $(4 \cdot 1 \mathrm{~cm} /$ year) was far below those of the other patients (fig 1). Her treatment was therefore changed to a non-methionyl growth hormone preparation after a year. Transient rises in concentrations of circulating immune complexes were noticed after three months of treatment in five girls (range 11-87\%). Another girl had a high value after nine months of treatment (31\%). After 12 months of treatment all measurements were within the normal range. In four of these six girls antibodies against growth hormone were found.

In eight children antibodies against $E$ coli proteins were detectable before treatment, but the titres were low $(0 \cdot 1-0 \cdot 8)$. During treatment the number of children in whom the antibodies were detected did not increase and the titres remained the same.

No adverse reactions were noted, compliance was good, and the girls were enthusiastic about the results. There were no problems with the daily injections of growth hormone.

\section{Discussion}

The effect of pituitary derived growth hormone on patients with Turner's syndrome has been described in a number of studies. Soyka $e t a^{11}$ and Tanner $e t$ $a l^{10}$ found little or no growth acceleration over a period of 12 months using doses as high as $18 \mathrm{mg}$ (presumably $18 \mathrm{IU}$ ) and 20 IU per week. Stahnke et al reported that six of eight patients with Turner's syndrome did not benefit from treatment with growth hormone. ${ }^{9}$ Other authors found significant increases in growth velocity in patients taking pituitary or biosynthetic growth hormone. ${ }^{812-16}$ Rosenfeld et al also reported a good growth response in the second year of treatment. ${ }^{30}$ In the period after treatment the growth velocity usually decreased to values before treatment, and in one study the acceleration during treatment was cancelled out by the deceleration after treatment. ${ }^{10}$

Ross $e t a l^{31}$ studied the dose response association between short term linear growth and growth hormone dosage, given three times a week. Lower leg length showed no increase with a growth hormone dose of $0.15 \mathrm{IU} / \mathrm{kg} /$ week, but increased significantly with doses of 0.45 and $1.35 \mathrm{IU} / \mathrm{kg} /$ week. The higher dose of $1.35 \mathrm{IU} / \mathrm{kg}$ was no more effective than that of $0.45 \mathrm{IU} / \mathrm{kg}$. In our study, daily somatrem $(0.9 \mathrm{IU} / \mathrm{kg} /$ week $)$ resulted in a considerable increment in growth velocity, which is higher 
1216 Rongen-Westerlaken, Wit, Drop, et al.

Table 3 Comparison of the results from different studies

\begin{tabular}{|c|c|c|c|c|c|}
\hline \multirow[t]{2}{*}{ Study } & \multirow{2}{*}{$\begin{array}{l}\text { Mean dose of } \\
\text { growth hormone } \\
\text { (IU/kg/week) }\end{array}$} & \multirow{2}{*}{$\begin{array}{l}\text { No of } \\
\text { injections/ } \\
\text { week }\end{array}$} & \multirow{2}{*}{$\begin{array}{l}\text { Mean }(S D) \\
\text { age (years) }\end{array}$} & \multicolumn{2}{|c|}{ Growth velocity (cm/year) } \\
\hline & & & & $\begin{array}{l}\text { Before } \\
\text { treatment }\end{array}$ & $\begin{array}{l}\text { Up to } 12 \\
\text { months after } \\
\text { treatment }\end{array}$ \\
\hline Rosenfeld $e t a l^{30}$ & Somatrem 0.9 & 3 & $9 \cdot 1(2 \cdot 1)$ & $4 \cdot 5$ & $6 \cdot 6$ \\
\hline Takano et $a^{15}$ & Somatrem $0 \cdot 2-0 \cdot 9$ & $2-4$ & $11 \cdot 5(1 \cdot 8)$ & 3.6 & $5 \cdot 5$ \\
\hline Raiti et $a l^{17}$ & $\begin{array}{l}\text { Human pituitary derived } \\
\text { growth hormone }\end{array}$ & 3 & Not known & $3 \cdot 2$ & $5 \cdot 9$ \\
\hline Present study & Somatrem 0.9 & 7 & $11 \cdot 7(2 \cdot 1)$ & $3 \cdot 4$ & $7 \cdot 2$ \\
\hline
\end{tabular}

*Conversion factor $1 \mathrm{mg}=2 \frac{1}{2} \mathrm{IU}$.

than the increments with $0 \cdot 6-0 \cdot 9 \mathrm{IU} / \mathrm{kg} /$ week given by three injections per week reported by other authors (table 3 ). When the results of Ross et al are extrapolated to one year periods, a dose of 0.9 $\mathrm{IU} / \mathrm{kg} /$ week should have no better effects than a dose of $0.6 \mathrm{IU} / \mathrm{kg} / \mathrm{week}$. This suggests that the better results in our study are due to giving the doses more often. This is in line with the reports that in children deficient in growth hormone daily doses of growth hormone have more effect on growth than doses given three times a week. ${ }^{18-20}$

Takano et $a l^{15}$ found antibodies against growth hormone in $60 \%$ of their patients at the end of 12 months of treatment with somatrem. In our patients the percentage was $73 \%$. Only one child had antibodies against growth hormone with a high binding capacity, and this child also had a poor growth response.

Bone age advanced by $1.0(0.4)$ years and the average height prediction increased by $1.8 \mathrm{~cm}$. These preliminary results and the results of the American collaborative study ${ }^{16}{ }^{30}$ suggest that the increased growth velocity may result in higher final heights. Long term follow up is required however, to determine whether this will be the case.

We thank Dr WHL Hackeng for measuring antibodies against growth hormone, the technicians of the pediatric laboratory in Nijmegen for measuring retinol binding protein, and Mrs B Batelaan-Hulshof and Mr T Schipper for administrative support and preparing the manuscript preparation. Kabivitrum gave generous financial support.

\section{References}

1 Snider ME, Solomon IL. Ultimate height in chromosomal gonadal dysgenesis without androgen therapy. Am J Dis Child 1974:127:673-4.

2 Ranke MB, Pflüger H, Rosendahl W, et al. Turner syndrome: spontaneous growth in 150 cases and review of the literature. Eur J Pediatr 1983;141:81-8.

${ }^{3}$ Lyon AJ, Preece MA, Grant DB. Growth curve for girls with Turner syndrome. Arch Dis Child 1985;60:932-5.

${ }^{4}$ Brook CGD, Mürset G, Zachmann M, Prader A. Growth in children with 45 XO Turner's syndrome. Arch Dis Child 1974;49:789-95
${ }^{5}$ Meadow SR, Boucher BJ, Mashiter K, King MNR, Stimmler L. Growth hormone seretion in subjects with ovarian dysgenesis and Turner's syndrome. Arch Dis Child 1968;43:595-7.

${ }^{6}$ Laczi F, Julesz J, Janaky T, Làszlò FA. Growth hormone reserve capacity in Turner's syndrome. Horm Metab Res 1979;11:664-6.

7 Ross JL, Long LM, Loriaux DJ, Cutler GB. Growth hormone secretory dynamics in Turner syndrome. $J$ Pediatr 1985; 106:202-6.

8 Rudman D, Goldsmith M, Kutner M, Blackston D. Effect of growth hormone and oxandrolone singly and together on growth rate in girls with $\mathrm{X}$ chromosome abnormalities. $J$ Pediatr 1980,96:132-5.

9 Stahnke N. Human growth hormone treatment in short children without growth hormone deficiency. $N$ Engl $J$ Med 1984;310:925-6.

10 Tanner JM, Whitehouse RM, Hughes PCR, Vince FP. Effect of human growth hormone treatment for 1 to 7 years on growth of 100 children with growth hormone deficiency, low birthweight, inherited smallness, Turner's syndrome and other complaints. Arch Dis Child 1971;46:745-82.

"Soyka LF, Ziskind A, Crawford JF. Treatment of short stature in children and adolescents with human pituitary growth hormone (Raben). N Engl J Med 1964;271:754-64.

12 Hutchings JJ, Escamilla RF, Li Ch, Forsham PF. Human growth hormone administration in gonadal dysgenesis. Am J Dis Child 1965;1099:318-21.

13 Wright JC, Brasel JA, Aceto T, et al. Studies with human growth hormone (hGH). Am J Med 1965;38:499-516.

14 Tzagouris M. Response to long-term administration of human growth hormone in Turner's syndrome. JAMA 1969;210: 2373-6.

15 Takano U, Mizuka N, Shizumek K. Growth hormone treatment in Turner's syndrome. Acta Paediatr Scand 1986;325:58-63.

16 Rosenfeld RG, Hintz RL, Johanson AJ, et al. Methionyl human growth hormone and oxandrolone in Turner syndromepreliminary results of a prospective randomized trial. J Pediatr 1986; 109:936-43.

17 Raiti S, Moore WV, van Vliet G, Kaplan SL. Growth stimulating effects of human growth hormone therapy in patients with Turner's syndrome. J Pediatr 1986;109:944-9.

18 Kastrup KW, Christiansen JS, Anderson JK, Orskov H. Increased growth rate following transfer to daily sc administration from three weekly im injections of hGH in growth hormone deficient children. Acta Endocrinol 1983;104:148-52.

19 Albertsson-Wikland K, Westphal O, Westgren U. Daily subcutaneous administration of human growth hormone in growth hormone deficient children. Acta Paediatr Scand 1986;75:89-97.

20) Hermanussen M, Geiger-Benoit K, Sippell WG. Catch-up growth following transfer from three times weekly im to daily sc administration of $\mathrm{hGH}$ in $\mathrm{GH}$ deficient patients, monitored by knemometry. Acta Endocrinol 1985;109:163-8. 
${ }^{21}$ Roede MJ, van Wieringen JC. Growth diagrams 1980 . Netherlands third nationwide survey. Tijdschrift Sociale Gezondheidszorg 1985;63(suppl):1-34.

22 Tanner JM, Whitehouse RH, Takaishi M. Standards from birth to maturity for height, weight, height velocity and weight velocity: British children 1965 part II. Arch Dis Child 1966;41:613-35.

${ }^{23}$ Tanner JM, Whitehouse RH, Cameron N, Marshall WA, Healy MJR, Goldstein H. Assessment of skeletal maturity and prediction of adult height (TW 2 method). 2nd ed. London: Academic Press, 1983.

${ }^{24}$ Ranke MB. Spontanes Wachstum beim Turner Syndrom. Normalwerte und Somatogramme nach dem 2. Lebensjahr. Der Kinderarzt 1985;9:1205-8.

25 Tanner JM, Whitehouse RH. Revised standards for triceps and subscapular skin folds in British children. Arch Dis Child 1975;50:142-5.

26 Venrooy-Ysselmuiden ME van. Growth and maturation of Dutch children. A mixed longitudinal study. Utrecht: State University, 1978. (Thesis.)

${ }^{27}$ Greulich WW, Pyle SI. Radiographic atlas of skeletal development of the hand and wrist. 2nd ed. California: Stanford University Press, 1959.

${ }^{28}$ Renckens ALJM, Janson MJH, van Munster PJJ, Weemaes
CMR, Bakkeren JAJM. Serum $x$ light-chain ratio in normal and diseased children: a nepholometric determination. Clin Chem 1986;32:2147-9.

29 Zubler RH, Lange G, Lambert PH, Miescher PA. Detection of immune complexes in unheated sera by a modified ${ }^{125} \mathrm{I}-\mathrm{C} 1 \mathrm{q}$ binding test. Effect of heating on the binding of $\mathrm{Clq}$ to immune complexes and application of the test to systemic lupus erythematosus. J Immunol 1976;116:232-5.

30 Rosenfeld RG, Hintz RL, Johanson AJ, Sherman B, and the Genentech collaborative group. Results from the first two years of a clinical trial with recombinant DNA-derived human growth hormone (somatrem) in Turner's syndrome. Acta Paediatr Scand 1987;331:59-66.

31 Ross JL, Long LM, Skerda M, Cassorla F, Loriaux and Cutler GB. Growth response relationship between growth hormone dose and short term growth in patients with Turner's syndrome. $J$ Clin Endocrinol Metab 1986;63:1028-30.

Correspondence to Dr C Rongen-Westerlaken, Wilhelmina Children's Hospital, Postbox 18009, 3501 CA Utrecht, The Netherlands.

Accepted 25 February 1988 